fying meeting in the country since he held office. And he was regarded as a personal friend by ever $y$ official of every club.

"Abroad Brancker was just as valuable an asset. He never let any foreigner think that British aviation was anything other than the very best in the world. He worked furiously hard, and he played as furiously hard, and he took an almost equal pride in each. His energy was seemingly inexhaustible. He could do a man's dav's work in his office, fly hundreds of miles, dance all night, and turn up merry and bright for work in the morning, and do it all over again. His was a most confusing character. We shall all miss him terribly. He was certainly not cut out for a peaceful odd age. That he should go in the fulness of his powers and of his popularity is far better.

"There's something in the theory, just made popular in The Bridge of San Luiz Rey, that each of us dies at the right time. Perhaps civil aviation no longer needs a leader of Brancker's type. Whatever may be, we must recognise the debt that we owe Sefton Brancker. And those of the younger generation of his friends, who called him familiarly ' little Branks,' may be better for understanding that in him they have known, at any rate, one man who has done good work as a soldier and as a civil servant for his King and for the people of this Empire."

\title{
Major George Herbert Scott, C.B.E., A.F.C., Fellow
}

Major George Herbert Scott was born in 1888 and educated at Richmond School, Yorkshire, and the Royal Naval Engineering College, Keyham. 'In 1914 he joined the Royal Naval Air Service as a Flight Sub-Lieutenant and served on the airship stations at Farnsworth and Kingsnorth. In $19 \mathbf{I}_{5}$ he went to Barrow and was appointed to the command of the Parseval P.4. In I9I7 he became the captain of the first British rigid airship. R.9. In 1918 he was appointed to command R.34, and was in command when the airship made the momentous crossing, in 19r9, to the United States and back, the first double crossing of the Atlantic by air. For this great pioneer flight Scott received the C.B.E.

In I920 Major Scott was appointed to the technical staff of the Royal Airship Works, at Cardington, and here he carried out his work on the mooring mast systems which now stand as monuments to his genius at Cardington, Cairo, Karachi and St. Hubert. Scott's inventive ability made it possible for airships to moor in the open for days on end in any weather. In 1924 he was appointed Officer in Charge of Flying and Training in the Airship Directorate, and in January, I930, Assistant Director (Flying).

It was under Scott's direction that the trials of R. Ioo and R. Ior were carried out, and he was the officer in charge on the recent flight of the former ship to Canada and back. Major Scott joined the Society in 1926 and was a Fellow. $\mathrm{He}$ served on the Council and was awarded the R. $3^{8}$ Memorial Prize in 1923 for his joint paper with I-ieut.-Colonel Richmond, entitled " A Detailed Consideration of the Effect of Meteorological Conditions on Airships." He read a number of papers before the Society on the mooring and handling of airships, which have become standard papers on the subject.

By the death of Major Scott we have lost a great airship captain, a great airship pioneer and a great airship enthusiast. A man of singular charm and modesty, he had a wide experience of which, in the ordinary way, he said very little. He was undismayed by set-backs, always heartening those with whom ne was associated by his constant cheerfulness and ready willingness to work unceasingly for the cause he had at heart. He had a sense of 'modesty in the extreme, never claiming any credit for himself, always willing to take the post of responsibility and danger. 